\section{PIERWSZA POLSKA ROZPRAWA Z RACHUNKU PRAWDOPODOBIEŃSTWA}

ŚLĄSKI

PRZEGLĄD

STATYSTYCZNY

Nr 13(19)

Witold Więsław

Uniwersytet Wrocławski

ISSN 1644-6739

e-ISSN 2449-9765

DOI: $10.15611 /$ sps.2015.13.16

Rzadko zdarza się w historii nauki, aby można było precyzyjnie określić, kiedy pojawiła się konkretna dyscyplina. W przypadku rachunku prawdopodobieństwa w Polsce sprawa jest prosta: pierwszym tekstem $\mathrm{z}$ rachunku prawdopodobieństwa w Polsce jest rękopis Jana Śniadeckiego [4], datowany na 1790 r., napisany jeszcze w czasie jego pobytu w Krakowie. Do tego czasu nie było w Polsce tekstów poświęconych tej dziedzienie, ani łacińskich, ani polskich.

Rozwój kombinatoryki, tak potrzebnej w elementarnym rachunku prawdopodobieństwa, datuje się od publikacji rozprawy Gotfrieda Wilhelma Leibniza [2].

Podręcznik [1] jest anonimowym tłumaczeniem z niemieckiego. Na stronie 100 znajduje się krótka wzmianka o kombinatoryce (Ars Combinatoria). Jest to jedyny podręcznik arytmetyki w języku polskim sprzed XIX w., w którym pojawiły się elementy kombinatoryki.

Tekst Śniadeckiego [4] ukazał się drukiem przed kilku laty [6]. Niniejsza publikacja jest jego przedrukiem. Dalsze informacje o rozwoju rachunku prawdopodobieństwa w Polsce można znaleźć w [5] i [8]. Rys życia Jana Śniadeckiego podaję w [7]. On sam w curriculum vitae [3] ograniczył się do pierwszych lat swojej kariery, w tym do opisu pobytu za granicą w latach 1778-1780. Wspomina tam, że w czasie pobytu w Paryżu słuchał wykładów wielu uczonych, nie tylko matematyków. Wśród nich byli: Nicolas de Condorcet i Jean d'Alembert. W tym czasie w Paryżu był też Pierre Simon de Laplace, autor słynnych dzieł poświęconych metodom analitycznym rachunku prawdopodobieństwa. Zapewne i z nim miał kontakt Śniadecki. Wszyscy trzej wymienieni matematycy zajmowali się probabilistyką. $\mathrm{Z}$ pewnością więc Śniadecki zdobył w Paryżu podstawową wiedzę w tym zakresie. 


\section{PRZEGLAD STATYSTYCZNY \\ Poniżej załączam tekst rękopisu Jana Śniadeckiego [4]. Zapocząt- kował on rachunek prawdopodobieństwa na ziemiach polskich.}

\section{Literatura}

[1] Arytmetyka podług reguł JMC. Pana Beniamina Hederichsa Rektora Szkół HAYN [...] DLA MŁODZY SZKOLNEY [...] W Warszawie 1774.

[2] Gottfredi Gvilielmi Leibnüzi Lipfenfis, ARS COMBINATORIA, In quæ Ex Arithmeticæ fundamentis Complictionum ac Tranfpofitionum Doctrina novis praeceptis exftruitur, \& ufus ambarum per univerfum fcientiarum orbem oftenditur; nova etam Artis Meditandi, Seu Logicae inventionis femina fparguntur, Præfixa eft Synopfis totius tractatus, et additamenti loco Demonftratis EXISTENTIÆ DEI, ad Mathematicam certitudinem exacta. FRANCOFURTI, Apud Henr, Christoph. Crökerum, Bibliopol. 1690.

[3] Jana Śniadeckiego Życie, przez Niego samego opisane. BJ rks 3141.

[4] Jan Śniadecki, Rachunek Zdarzeń i Przypadków Losu. BJ rks 3161/6.

[5] Witold Więsław, Pierwsze polskie teksty z rachunku prawdopodobieństwa (w tomie: Wokót Bernoullich, Materiały z XIX Ogólnopolskiej Szkoły Historii Matematyki, Zamość 6-10 czerwca 2005, red. W. Więsław, Politechnika Lubelska, Lublin 2006), s. $101-108$.

[6] Witold Więsław, Jana Śniadeckiego Rachunek Zdarzeń i Przypadków Losu z roku 1790 (w tomie: Wokót Bernoullich, Materiały z XIX Ogólnopolskiej Szkoły Historii Matematyki, Zamość 6-10 czerwca 2005, red. W. Więsław, Politechnika Lubelska, Lublin 2006), s. 109-129.

[7] Witold Więsław, Jan Śniadecki (1756-1830) - uczony, mąż stanu, patriota, Antiquitates Mathematicae 2007,Vol. 1, s. 173-197.

[8] Początki rachunku prawdopodobieństwa na ziemiach polskich (w tomie: $N a$ ścieżkach historii statystyki, red. W. Ostasiewicz, Wydawnictwo Uniwersytetu Ekonomicznego we Wrocławiu. Wrocław 2013), rozdz. 5, s. 99-131. 


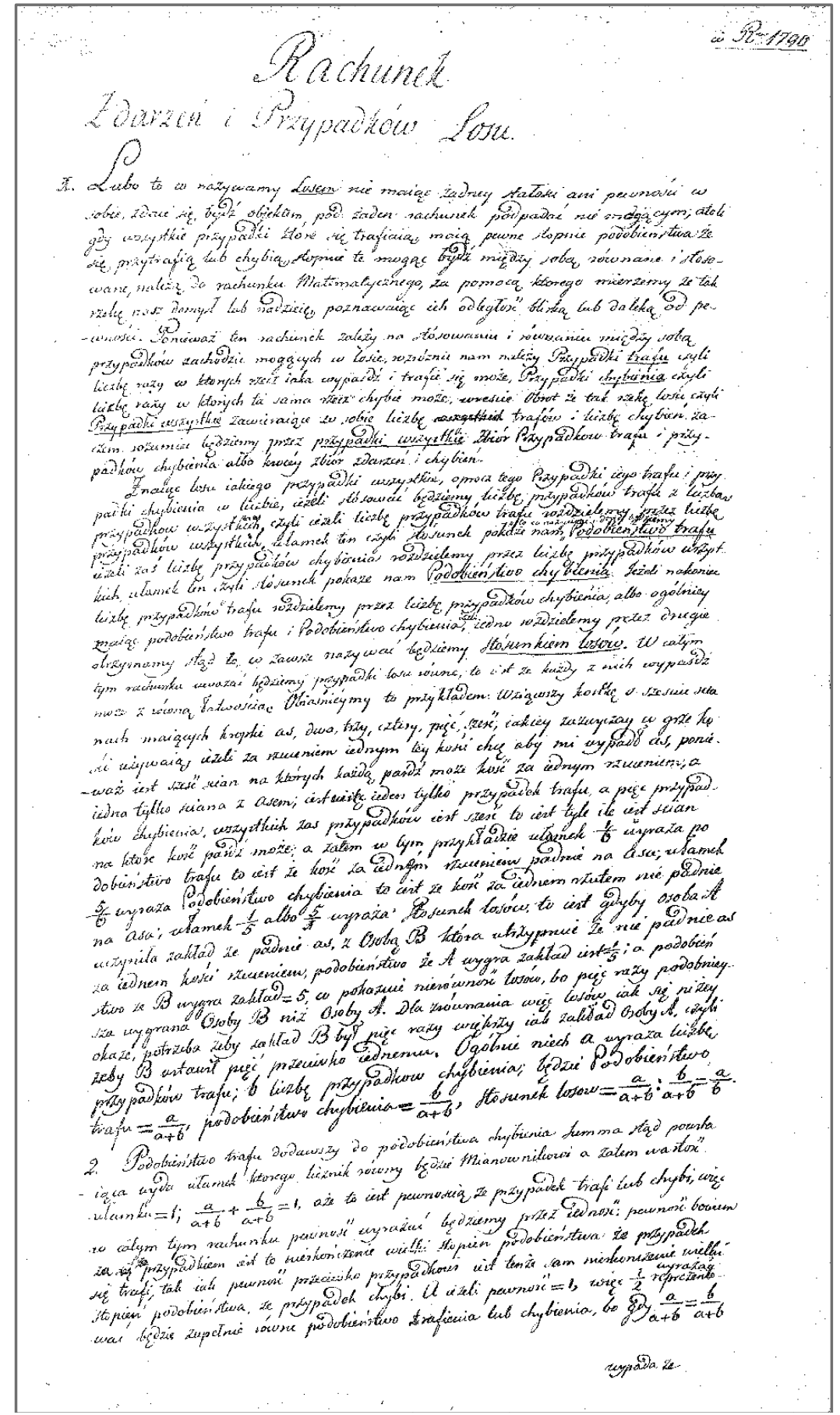

Rys. 1. Pierwsza strona rękopisu [4] Jana Śniadeckiego. 


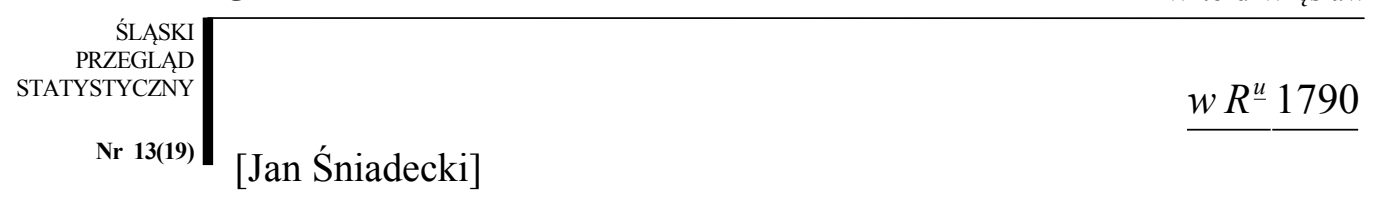

\section{Rachunek}

\section{Zdarzeń i Przypadków Losu}

1. Lubo to co nazywamy Losem nie maiąc żadney stałosci ani pewności w sobie, zdaie się bydź obiektem, pod żaden rachunek podpadać nie mogącym, atoli gdy wszystkie przypadki które się trafiaią maią pewne stopnie podobieństwa że się przytrafią lub chybią, stopnie te mogąc bydź między sobą równane i stosowane, należą do rachunku Matematycznego, za pomocą którego mierzemy że tak rzekę, nasz domysł lub nadzieię, poznawaiąc ich odległość bliską lub daleką od pewności. Ponieważ ten rachunek zależy na stósowaniu i równaniu między sobą przypadków zachodzić mogących w losie, rozrożnić nam należy Przypadki trafu czyli liczbę razy w ktorych rzecz iaka wypaśdź i trafić się może. Przypadki chybienia czyli liczbę razy w ktorych ta sama rzecz chybić może, wreszcie obrót że tak rzekę losu, czyli Przypadki wszystkie zawieraiące w sobie liczbę wszystkch trafów i liczbę chybień. Zaczem rozumieć będziemy przez przypadki wszystkie Zbiór Przypadkow trafu i przypadków chybienia albo krocéy zbiór zdarzeń i chybień.

Znaiąc losu iakiego przypadki wszystkie, oprocz tego Przypadki iego trafu i przypadki chybienia w liczbie, ieżeli stósować będziemy liczbę przypadków trafu z liczbą przypadków wszystkich, czyli ieżeli liczbę przypadków trafu rozdzielimy przez liczbę przypadków wszystkich, ułamek ten czyli stósunek pokaże nam to co nazywać odtąd będziemy Podobieństwo trafu ieżeli zaś liczbę przypadków chybienia rozdzielemy przez liczbę przypadków wszystkich, ułamek ten czyli stósunek pokaże nam Podobieństwo chybienia. Ieżeli nakoniec liczbę przypadków trafu rozdzielemy prze liczbę przypadków chybienia, albo ogólniey, znaiąc podobieństwo trafu i Podobieństwo chybienia, ieżeli iedno rozdzielemy przez drugie otrzymamy stąd to co zawsze nazywać będziemy Stósunkiem losów. W całym tym rachunku uważać będziemy przypadki losu równe, to iest że każdy z nich wypaśdź $z$ równą łatwością. Obiaśnieymy to przykładem: wziąwszy kostkę o szesciu scianach maiących kropki as, dwa, trzy, cztery, pięć, sześć, iakiey zazwyczay w grze kości używaią, ieżeli za rzuceniem iednym tey kości chcę aby mi wypadł as, ponieważ iest sześć ścian na 
których każdą paśdź może kość za iednym rzuceniem, a iedna tylko sciana $\mathrm{z}$ asem; iest więc ieden tylko przypadek trafu, a pięć przypadków chybienia, wszystkich zas przypadkow iest sześć, to iest tyle ile STATYSTYCZNY iest scian na które paśdź może; a zatem w tym przykładzie ułamek $\frac{1}{6}$ wyraża podobieństwo trafu to iest że kość za iednym rzuceniem padnie na asa; ułamek $\frac{5}{6}$ wyraża Podobieństwo chybienia to iest że kość za iednem rzutem nie padnie na asa; ułamek $\frac{1}{5}$ albo $\frac{5}{1}$ wyraża Stosunek losów, to iest gdyby osoba $A$ uczyniła zakład że padnie as, z osobą $B$ która utrzymuje że nie padnie as, za iednem kości rzuceniem, podobieństwa że $A$ wygra zakład iest $=\frac{1}{5}$; a podobieństwo że $B$ wygra zakład $=5$, co pokazuie nierówność losów, bo pięć razy podobnieysza wygrana Osoby $B$ niż Osoby $A$. Dla zrównania więc losów iak się niżey okaże, potrzeba żeby zakład $B$ był pięć razy większy iak zakład Osoby $A$, czyli żeby $B$ ustawił pięć przeciwko iednemu. Ogólnie niech $a$ wyraża liczbę przypadków trafu; $b$ liczbę przypadków chybienia; będzie Podobieństwo trafu $=\frac{a}{a+b}$, podobieństwo chybienia $=\frac{b}{a+b}$, stosunek losów $=\frac{a}{a+b}: \frac{b}{a+b}=\frac{a}{b}$.

2. Podobieństwo trafu dodawszy do podobieństwa chybienia Summa stąd powstaiąca wyda ułamek ktorego licznik równy będzie Mianownikowi a zatem wartość ułamku $=1 ; \frac{a}{a+b}+\frac{b}{a+b}=1$, aże to iest pewnością że przypadek trafi lub chybi, więc w całym tym rachunku pewność wyrażać będziemy przez iedność: pewność bowiem za przypadkiem iest to nieskończenie wielki stopień podobieństwa że przypadek się trafi, tak iak pewność przeciwko przypadkowi iest tenże sam stopień podobieństwa, że przypadek chybi. A ieżeli pewność $=1$, więc $\frac{1}{2}$ reprezentować [dopisane: wyrażać] będzie zupełnie równe podobieństwo trafienia lub chybienia, bo gdy $\frac{a}{a+b}=\frac{b}{a+b}$ [Rachunek losów, str. 2] wypada że $a=b$ a zatem wartość obydwóch ułamków $=\frac{1}{2}$. $1-\frac{b}{a+b}=\frac{a}{a+b}, 1-\frac{a}{a+b}=\frac{b}{a+b}$ to iest od pewności odciągnąwszy podobieństwo chybienia, wypada podobieństwo trafu; i od teyże pewności odciągnąwszy podobieństwo trafu, reszta okaże podobieństwo chybienia. 
[na lewym marginesie: oczekiwanie iego wartości]

Nr 13(19) Jeżeli za zdarzeniem się iakiego przypadku, wygrywa kto pewną sumę pieniędzy, iego Oczekiwanie tey summy, ma pewną wartość przed trafieniem się tego przypadku. Tak n. p. ieżeli kto ma wygrywać \#10 za wypadkiem iakiego zdarzenia na ktore zupełnie iest równe podobieństwo ze trafi lub chybi, oczekiwanie iego przed wypadkiem losa iest $=\# 5$. czyli warta $5^{\#}$. gdyż oczekuiący iest tu zupełnie $w$ takich okolicznościach, iak gdyby $\mathrm{w}$ rowney grze stawił $5^{\#}$, aby za wygraną miał ich 10 , albo stracił 5 za chybieniem gry; aże wstawiaiący $5^{\#} \mathrm{~W}$ równéy grze iest włascicielem $5^{\#}$ przed decyzyą gry, więc podobnie oczekuiący na wygraną 10 za wypadkiem iakiego zdarzenia przed decyzyą losu iest w stanie oczekiwania które warta $5^{\#}$.

We wszystkich zdarzeniach w ogólności oczekiwanie na wygranie iakiéy Summy ma wartość równą Summie Pieniędzy oczekiwaney rozmnożonéy przez Podobieństwo trafu. I tak ieżeli w 5 przypadkach losu ma za sobą trzy do otrzymania $100^{\#}$ moie oczekiwanie $=\frac{3}{5} \cdot 100=60^{\#}$. Prawdę tego twierdzenia obiasnic możemy przykładem. Niech będzie pięć biletów loteryi do wyciągnienia między ktoremi znayduią się cztery bilet prożne, a piąty wartaiący \#100, i pięc osób do ciągnienia tey loteryi; rzecz oczywista że każda z osob ciągnących ma prawo do $\frac{1}{5}$ części $100^{\#}$, ktore to prawo zależy natém, iż gdyby się wszystkie pięć osób zgodziły nie ciągnąc losu, ale rozdzielić Summę oczekiwaną między siebie, każdey z nich przypadłoby $\frac{1}{5} 100^{\#}$ za iéy pretensyą. Czyli zaś Osoby ciągnące zgodzą się na rozdzielenie między siebie Summy, czyli też poddadzą się przypadkowi losu, zadna z nich nie ma więcey za sobą, lub przeciwko sobie przypadków do wygrany, tylko tyle ile ich ma kazda z nich, to iest wszystkie są w równych okolicznościach, a zatem każdey oczekiwanie warte $\frac{1}{5} 100^{\#}$. Wystawmy sobie teraz że dwie spomiędzy pięciu osob interessowanych do wygrany ustępuią swego prawa do trzeciéy osobie $\mathrm{z}$ pomiędzy siebie, więc osoba ktora pozyskała ustąpienie losow dwoch inszych, ma teraz trzy razy większe prawo do wygrany iak przedtym, a zatem oczekiwanie tey Osoby warta $\frac{3}{5} \cdot 100^{\#}=60^{\#}$. Aze ułamek $\frac{3}{5}$ wyraża Podobieństwo trafu czyli podobieństwo otrzymania $100^{\#}$, \#100 wyraża Summę oczekiwaną z wygrany, więc to cośmy powiedzieli wyżéy iest prawdziwe: że Oczekiwanie rowna się Summie spodziewanéy z wygraney, rozmnożonéy przez podobieństwo trafu. Lubo 
ten sposob dowodzenia wyciągniony iest z przypadku szczególnego, atoli łatwo się przekonać że ta prawda ma miéysce we wszystkich zdarzeniach losu, i iest ogólną.

S tego cośmy dopiero rzekli wypada iż maiąc wartość oczekiwania, i Summę spodziewaną z wygrany, rozdzieliwszy pierwszą przez drugą otrzymamy podobieństwo trafu. W poprzedzaiącym przykładzie oczekiwanie było $=60^{\#}$, Summa spodziewana $100^{\#} ; \frac{60}{100}=\frac{6}{10}=\frac{3}{5}=$ Podobieństwo trafu.

[na lewym marginesie: narażenie się na stratę czyli rysk w grze]

3. Narażenie sie na strate czyli to co nazywaią rysk w grze iest przeciwne oczekiwaniu, i wartość iego iest równa Summie ustawioney czyli krocéy Wstawie rozmnożoney przez podobieństwo chybienia. $\mathrm{W}$ poprzedzaiącym przykładzie ieżeli ten ktorego oczekiwanie $=60^{\#}$, ustawił $20^{\#}$, iego Podobieństwo trafu $=\frac{3}{5}$, Podobieństwo chybienia $=\frac{2}{5}$, więc narażenie sie na Stratę $=20 \cdot \frac{2}{5}=8^{\#}$.

Kombinując różne oczekiwania i narażenia się na statę graczów, wypada stąd co nazywać będziemy w ciągu teraźnieyszego rachunku korzyścia lub strata w grze; a co pospolicie nazywać się zwykło Awantażem lub dezawantażem; i lubo nie masz rzetelney korzyści ani straty przed wypadkiem losu gry, ale że puszczaiący się w grze na przypadek losu zamierza sobie zyskać lub stracić, przeto przez wzgląd na przedsięwzięcie graiących użyć możemy tych słów nie maiąc $\mathrm{w}$ naszym ięzyku własciwszych do wyrażenia tego co nazywaią Awantażem lub dezawantażem.

[Rachunek losów, str. 3]

Jeżeli Osoby $A$ i $B$ graią razem tak, że $A$ wstawił $5^{\#}$, a $B 3^{\#}$, liczba przypadkow ktore ma za sobą $A$ do wygrany $=4$, liczba zaś podobnych przypadków, które ma za sobą $B=2$, więc Summa do wygrania $=8^{\#}$. [na prawym marginesie: znalezienie korzyści lub straty $\mathrm{w}$ grze] Podobieństwo trafu dla $A=\frac{4}{6}$, oczekiwanie $A=8 \cdot \frac{4}{6}=5 \frac{1}{3}$. Podobieństwo trafu dla $B=\frac{2}{6}$, Oczekiwanie $B=8 \cdot \frac{2}{6}=2 \frac{2}{3}$. Od oczekiwania każdego odciągnąwszy własą iego wstawkę wypadnie korzyść lub strata $\mathrm{w}$ grze, to iest korzyść ieżeli reszta będzie dodatna, strata zaś ieżeli reszta będzie odiemna. I tak $5 \frac{1}{3}-5=\frac{1}{3}$ korzyść $A: 2 \frac{2}{3}-3=-\frac{1}{3}$ strata dla $B$ w przytoczonym przykładzie. 
Wynaleśdź ieszcze można korzyść lub stratę w grze odciągaiąc od oczekiwania każdego gracza względem Summy iego przeciwnika, narażenie na stratę własnéy swoiéy wstawki a zatem oczekiwanie tu nie powinno się rachować względem Summy całkiéy ale tylko względem Summy szczególney przeciwnika; w narażeniu się zaś na stratę uważać powinniśmy samę tylko wstawkę tego ktorego szukamy korzyści lub straty, i od pierwszego odciągnąwszy drugie wypadnie reszta dodatna lub odiemna ktora okaże korzyść lub stratę. W Przykładzie ostatnim wstawka $B=3^{\#}$, Podobieństwo trafu $A=\frac{4}{6}$, Oczekiwanie $A$ na wstawkę $B=3 \cdot \frac{4}{6}=2$, Wstawka $A=5^{\#}$.

Podobieństwo chybienia dla $A=\frac{2}{6}$, Narażenie się $A$ na stratę $=5 \cdot \frac{2}{6}=1 \frac{2}{3}$. Oczekiwanie $A$ naraz na stratę $A$, czyli $2-1 \frac{2}{3}=\frac{1}{3}$ korzyść $A$. Podobieństwo trafu $B=\frac{2}{6} ; 5^{\#}=$ wstawie $A$, oczekiwanie $B$ na tę wstawkę $=5 \cdot \frac{2}{6}=1 \frac{2}{3}$; Podobieństwo chybienia dla $B=\frac{4}{6}$, Narażenie się na stratę $=3 \cdot \frac{4}{6}=2$. Oczekiwanie $B$ na wstawkę 5 . Narażenie się na stratę czyli $1 \frac{2}{3}-2=-\frac{1}{3}$

strata $B$ tak iak przedtym. Wyraźmy to wszystko ogólnemi znakami.

Niech będzie dwoch graczow $A, B$, liczba przypadkow przyiaznych albo trafu dla $A=a$, liczba przypadkow przyiaznych albo trafu dla $B=$ $b$, Wstawka $A=m$, Wstawka $B=n$, więc:

Podobieństwo Trafu $A=\frac{a}{a+b}$, Podobieństwo chybienia dla $A=\frac{b}{a+b}$ Podobieństwo Trafu $B=\frac{b}{a+b}$, Podobieństwo chybienia dla $B=\frac{a}{a+b}$ Oczekiwanie $A=\frac{(m+n) a}{a+b}$, Narażenie się na stratę $A=\frac{m b}{a+b}$ Oczekiwanie $B=\frac{(m+n) b}{a+b}$, Narażenie się na stratę $B=\frac{n a}{a+b}$ Oczekiwanie $A$ na wstawkę $n=\frac{n a}{a+b} ; \frac{(m+n) a}{a+b}-m=\frac{n a-m b}{a+b}$ korzyść lub strata w grze dla $A$ Oczekiwanie $B$ na wstawkę $m=\frac{m b}{a+b} ; \frac{(m+n) b}{a+b}-n=\frac{m b-n a}{a+b}$ korzyść lub strata w grze dla $B$ [na prawym marginesie: Przypadki zawisłe i niezawisłe] 
4. Nazywać będziemy Przypadki niezawisłe ktore nie maią żadnego z sobą związku tak dalece że zdarzenie się iednego ani pomaga ani przeszkadza do zdarzenia się drugiego. I tak żeby kto przedsięwziął za STATYSTYCZNY dwoma rzutami téy samey kości wrzucić asa, rzut ieden kości nic nie wpływa w rzut drugi kości, bo rzucaiący iak w pierwszym tak drugim rzucie ma ieden tylko przypadek trafu, a pięć przypadków chybienia i dla tego dwa te rzuty iedney kości są przypadkami niezawisłemi.

Nazywać znowu będziemy Przypadki zawisłe które maią między sobą taki związek iż zdarzenie się iednego wpływa i odmienia Podobieństwo trafu drugiego. Gdyby kto chciał z pomiędzy 13 kart za iedném, drugiem, trzeciem, i więcey ciągnieniem trafić na asa; przed pierwszém ciągnieniem w 13 kartach iest ieden przypadek trafu, a 12 przypadków chybienia. Podobieństwo trafu $=\frac{1}{13}$; wyciągnąwszy iednę kartę i tę na bok odłożywszy zostaie ich się 12 gdzie 1 przypadek trafu a 11 chybienia, Podobieństwo trafu $\mathrm{w}$ drugiém ciągnieniu $=\frac{1}{12} ; \mathrm{w}$ trzeciém ciągnieniu $\frac{1}{11}$; i tak daley: dlatego te przypadki nazywaią się zawisłe.

[na prawym marginesie: Podobieństwo trafu w wielu przypadkach niezawisłych]

Uważaiąc kilka losów razem poznać nam należy kombinacyą przypadków iednego z przypadkami inszych, aby znaleść zbiór przypadków wszystkich wchodzących do podobieństwa trafu. Niech $a$ będzie liczbą przypadków trafu, $b$ liczbą przypadków chybienia na ieden los; $c$ liczbą przypadków trafu, $d$ liczbą przypadków chybienia na drugi los; [Rachunek losów: str. 4] $a+b$ wyrażać będzie Summę przypadków wszystkich pierwszego losu, $c+d$ Summę przypadków wszystkich drugiego losu poiedynczo wziętego, aże przypadki pierwszego kombinuiąc zkażdym przypadkiem drugiego losu, wypadnie liczba przypadków wszystkich w obydwoch losach $=(a+b)(c+d)$.

Przez ten sam sposób rozumowania maiąc $a, c, e, \& c$. liczbę przypadków trafu, $b, d, f$, \&c. liczbę przypadków chybienia na trzy lub więcey zdarzeń nie zawsze liczba wszystkich mogących wypaśdź przypadków będzie $=(a+b)(c+d)(e+f) \& c$. to iest mnożąc przez siebie summy przypadków wszystkich każdego w szczegolności zdarzenia, otrzymamy kombinacyą przypadków wszystkich zdarzeń, czyli liczbę wszystkich podobnych i zdarzyć się mogących przypadków w obrocie losów. Wziąwszy ich za przykład dwa, liczba rozmnożenia $a c+a d+b c+b d$ złożona z mnogości szczególnych, zamyka wła- 
ściwe znaczenia tychże mnogości, i tak ac wyraża liczbę przypadków trafu na dwa na obydwa razem losy; $b d$ wyraża Summę przypadków chybienia na obydwa razem losy, czyli zbiór przypadków że obydwa losy chybią; $a c+a d$ że pierwszy trafi; $b c+b d$ że pierwszy chybi; $a c+a d+b c$ że ieden tylko którykolwiek z nich trafi i.t.d. Tymże samym sposobem o liczbie większey losów rozumuiąc rozróżnić możemy w ich Summie wyrazy maiące do siebie przywiązane znaczenie przypadków trafu lub chybienia we wszystkich kombinacyach zachodzić mogących.

Z liczby przypadków chcąc doyśdź podobieństwa trafu na dwa lub więcey losów należy liczbę przypadków trafu rozdzielić przez liczbę wszystkich zdarzyć się mogących przypadków, na dawa losy, których przypadki trafu są $a, c$, przypadki chybienia $b, d$; $a c$ wyraża zbiór przypadków trafu obydwóch losów, więc $\frac{a c}{(a+b)(c+d)}=$ Podobieństwo trafu, aże $\frac{a c}{(a+b)(c+d)}=\frac{a}{a+b} \times \frac{c}{c+d}$, a ułomki $\frac{a}{a+b}, \frac{c}{c+d}$ wyrażaią Podobieństwa trafu na losy poiedyńczo uważane, więc podobieństwo trafu na kilka lub tyle ile nam się podoba losów niezawisłych otrzymuie sie przez rozmnożenie ułomków pokazuiących podobieństwa trafu na każdy w szczególności los poiedyńczo uważany. I tak niech będą trzy losy $A, B, C$, liczba przypadków trafu pierwszego $a$, przypadków chybienia $b$; liczba przypadków trafu $c$, przypadków chybienia na drugi los $d$; liczba przypadków trafu $e$, przypadków chybienia $f$ na trzeci los; że wszystkie trzy przypadki trafią wyraża ace, liczba wszystkich mogących się przytrafić przypadków iest $=(a+b)(c+d)(e+f)$ więc Podobieństwo trafu na wszystkie trzy $=\frac{a c e}{(a+b)(c+d)(e+f)}=\frac{a}{a+b} \times \frac{c}{c+d} \times \frac{e}{e+f}$; Rownie otrzymuiemy Podobieństwo chybienia, gdyby ich było dwa $b d$ wyraża przypadki że obydwa losy chybią; więc $\frac{b d}{(a+b)(c+d)}=\frac{b}{a+b} \times \frac{d}{c+d}=$ Podobieństwo chybienia obu [losów?]; gdyby ich było trzy, bdf wyraża przypadki że wszystkie trzy losy chybią, więc Podobieństwo chybienia trzech $=\frac{b d f}{(a+b)(c+d)(e+f)}=\frac{b}{a+b} \times \frac{d}{c+d} \times \frac{f}{e+f} ;$

Przez podobieństwo trafu mnożąc Summę pieniędzy spodziewaną, otrzymamy wartość oczekiwania podług §.2. Przypuśćmy dla przy- 
kładu że dla otrzymania Summy $90^{\#}$ potrzeba zdarzenia dwóch losów z których pierwszy ma trzy przypadki trafu, a 2 przypadki chybienia; drugi ma 4 przypadki trafu, a 5 chybienia. Podobieństwo trafu $\mathrm{w}$ pierwszym $=\frac{3}{5} \mathrm{w}$ drugim $\frac{4}{9}$, więc oczekiwanie $=\frac{3}{5} \cdot \frac{4}{9} \cdot 90=\frac{360}{15}=24^{\#}$. Zaiste chcąc się o tym przekonać wystawmy sobie że się pierwszy los iuż trafił a zatem oczekiwanie zawisłe będąc zupełnie od drugiego losu, będzie przed iego zdarzeniem $=\frac{4}{9} \cdot 90=40^{\#}$. Teraz zapatrywać się możemy na pierwszy los iako warunek potrzebny do otrzymania $40^{\#}$, aże Podobieństwo trafu pierwszego losu $=\frac{3}{5}$, więc oczekiwanie do otrzymania $40^{\#}$ iest $=\frac{3}{5} \cdot 40=24^{\#}$ iak przedtym.

Gdyby oczekiwanie zawisło od zdarzenia się iednego losu a od chybienia drugiego, wartość tego oczekiwania będzie mnogością powstaiącą z rozmnożenia Podobieństwa trafu pierwszego losu przez Podobieństwo chybienia drugiego, a potem przez Summę spodziewaną pieniędzy. Gdyby zaś oczekiwanie zawisło od chybienia dwoch lub więcey losów [str. 5] [na marginesie: Rachunek Losow 1790] wartość oczekiwania wypadnie z mnogości dwoch Podobieństw chybienia przez Summę spodziewaną. To prawidło łatwo będzie rozciągnąc do więcey zdarzeń $\mathrm{w}$ przypadkach i losach niezawisłych, i niżey przyidzie nam ieszcze rzecz tę rozlegley powtórzyć.

[na prawym marginesie: Podobieństwo trafu, chybienia, oczekiwanie w przypadkach zawisłych]

5. w Przypadkach zawisłych powiedzieliśmy że zdarzenie się iednego losu wpływa i odmienia Podobieństwo trafu drugiego. Gdyby sobie kto założył z kart 13 iednego koloru wyciągnąc naprzód Asa, potem dwoykę. Na pierwszy los że wyciągnie Asa podobieństwo trafu $=\frac{1}{13}$, przypuśćmy że się zdarzył los pierwszy, zostało się na los drugi kart 12, a zatem podobieństwo trafu na ten los przypuściwszy pierwszy iako zdarzony, podobieństwo mówię trafu $=\frac{1}{12}$ więc że się obydwa losy trafią Podobieństwo trafu $=\frac{1}{12} \cdot \frac{1}{13}=\frac{1}{156}$ skąd się wnosi że podobieństwo na dwa losy zawisłe iest mnogością wypadaiącą z rozmnożenia Podobieństwa trafu iednego losu przez podobieństwo trafu drugiego uważanego tak iak gdyby się pierwszy trafił.

Lecz nayłatwieyszy sposób wynalezienia Podobieństwo trafu różnych losów zawisłych, iest rozróżnić myślą porządek tych losów wystawiaiąc sobie który z nich pierwszy, drugi, trzeci, i.t.d. w porządku 
należy uważać, potym podobieństwo trafu pierwszego losu uważać iak niezawisłe od inszych; podobieństwo trafu drugiego należy uważać w tym przypuszczeniu iak gdyby się pierwszy los iuż zdarzył, Podobieństwo trafu trzeciego należy uważać iak gdyby się dwa pierwsze losy iuż zdarzyły. Podobieństwo czwartego iak gdyby się trzy pierwsze iuż zdały i.t.d. Wreszcie podobieństwo trafu na wszystkie razem będzie rowne Mnogości z Podobieństw wszystkich trafu determinowanych sposobem dopiero podanym.

S tego cośmy dotąd powiedzieli wniesiemy łatwo, iż sposób determinowania Podobieństwo trafu na tyle przypadków zawisłych lub niezawisłych, ile nam ich sobie podoba wystawić nie ma żadney trudności, ieżeli to podobieństwo zawisło od zdarzenia się przypadków różnych losów. Ale na przypadki zawisłe ieżeli podobieństwo trafu zależy od zdarzenia się iednych i razem od chybienia drugich losów zawiera w sobie wielkie trudności, dla ktorych podanie reguł na wynalezienie takiego podobieństwa odkładamy do przepisów niżey podadź się maiących.

[na prawym marginesie: oczekiwanie na różne Summy]

6. Oczekuiąc na rożne Summy wygrany, łatwo się przekonać że oczekiwanie na całą Summę wygrany, składa się z oczekiwań ktore mam na Summy szczególne, iest równe zbiorowi z oczekiwań na te szczegolne Summy. Itak, n.p. wystawmy sobie dwa losy z których ieden ma cztery przypadki trafu, a pięć przypadków chybienia, drugi ma 3 przypadki trafu a dwa chybienia. Jeżeli się trafi pierwszy, wygrana iest $90^{\#}$, a ieżeli się także trafi i drugi podobna wygrana iest $90^{\#}$, iakaż iest wartość oczekiwania na całą wygraną z z obydwoch losów przypadaiącą? Na pierwszy los podobieństwo trafu $=\frac{4}{9}$, Summa spodziewana $90^{\#}$ więc oczekiwanie na zdarzenie się tego losu $=\frac{4}{9} \cdot 90=40^{\#}$. W drugim losie podobieństwo trafu iest $=\frac{3}{5}$, Summa spodziewana $90^{\#}$ więc wartość oczekiwania $\mathrm{z}$ drugiego losu $90^{\#} \cdot \frac{3}{5}=54^{\#}$. A zatem oczekiwanie na całą wygraną z obydwóch losów przypadaiącą $40^{\#}+54^{\#}=94^{\#}$.

Lecz gdy $90^{\#}$ przychodziło raz tylko wygrywać na zdarzenie się iednego z dwóch dopiero opisanych losów, sposób determinowania wartości oczekiwania będzie inny; albowiem lubo z pierwszego losu oczekiwanie warte iest $40^{\#}$ iednakowoż zważyć należy, że oczekiwanie na drugi los zginie, za zdarzeniem się losu pierwszego, i że to 
oczekiwanie na los drugi nie ma mieysca tylko w [Rachunek Losów: str.6] tym przypadku kiedy pierwszy los chybi. Że pierwszy los chybi iest podobieństwo równe $\frac{5}{9}$, a przypuściwszy że chybił, na ten czas oczekiwanie może będzie warte $54^{\#}$, gdzie $\frac{5}{9}$ będąc miarą oczekiwania mego na $54^{\#}$, wypada że to oczekiwanie /szacuiąc go przed determinacyą losu pierwszego czyli nim pierwszy los zapadnie/ warte iest $\frac{54 \cdot 5}{9}=30^{\#}$, a zatem wartość całego oczekiwania będzie $=40+30=70^{\#}$.

Dla wprawienia się w użycie dopiero wyłożonych prawideł, przyłączaią się tu do rozwiązania przykłady następuiące

Przykład I. Gra w kości Znaleśdz Podobieństwo trafu na wrzucenie Asa za dwoma rzutami kości.

Podobieństwo trafu na wrzucenie Asa za pierwszym rzutem iest $=\frac{1}{6}$ i to iest pierwsza część szukanego podobieństwa.

Chybiony As za pierwszym rzutem zawsze może bydź wrzucony za drugim, aże podobieństwo chybienia go za pierwszym rzutem $=\frac{5}{6}$, a podobieństwo wrzucenia go za drugim rzutem $=\frac{1}{6}$ więc Podobieństwo chybienia go za pierwszym a wrzucenia go za drugim rzutem $=\frac{5}{6} \cdot \frac{1}{6}=\frac{5}{36}$ i to iest druga część podobieństwa szukanego, przeto Podobieństwo trafu szukane $\frac{1}{6}+\frac{5}{36}=\frac{11}{36}$.

Podobne byłoby zagadnienie o wrzuceniu 6 lub 7 za dwoma rzutami we dwie kości co łatwo bydź może rozwiązane zważywszy że 7 ma 6 przypadków trafu $\mathrm{w}$ dwóch kościach, 6 ma zaś ich tylko 5; wszystkich zaś przypadków we dwóch kościach znayduie się 36; iest zatem przypadków trafu na wrzucenie 7 lub 6 za pierwszym rzutem 11, więc Podobieństwo trafu na pierwszy rzut $=\frac{11}{36}$; lecz chybiwszy oboie za pierwszym rzutem, iedno z nich bydź może wrzucone za drugim rzutem. Podobieństwo chybienia za pierwszym rzutem iest $\frac{25}{36}$, Podobieństwo trafu na ktorekolwiek za drugim rzutem $=\frac{11}{36}$, skąd Podobieństwo chybienia za pierwszym, a trafieniana ktorekolwiek za drugim rzutem $=\frac{25}{36} \cdot \frac{11}{36}=\frac{275}{1296}$, a przeto Podobieństwo szukane $=\frac{11}{36}+\frac{275}{1296}=\frac{671}{1296}$. 
Przykład II. Znaleśdź podobieństwo trafu na wrzucenie Asa za trzema rzutami kości.

Że As będzie wrzucony za pierwszym rzutem iest podobieństwo trafu $=\frac{1}{6}$; Jeżeli As będzie chybiony za pierwszym rzutem, może bydz trafiony za drugim i trzecim, aże podobieństwo chybienia za pierwszym rzutem $=\frac{5}{6}$, a podobieństwo trafienia za dwoma rzutami $=\frac{11}{36}$ (podług Przyk. I) więc podobieństwo chybienia go za pierwszym, a wrzucenia go za dwoma następuiącemi rzutami $=\frac{5}{6} \cdot \frac{11}{36}=\frac{55}{216}$ co iest drugą częścią podobieństwa szukanego, więc szukane podobieństwo iest $\frac{1}{6}+\frac{55}{216}=\frac{91}{216}$.

Przykład III. Znalesdz podobieństwo trafu na wrzucenie Asa za czterema rzutami kości.

Podobieństwo wrzucenia Asa za pierwszym rzutem $=\frac{1}{6}$; to iest pierwsza część podobieństwa szukanego. Gdyby as chybił za pierwszym rzutem na co podobieństwo $=\frac{5}{6}$, zostaną się trzy rzuty $\mathrm{w}$ ktorych że As wypadnie podług Przykł. II iest podobieństwo $\frac{91}{216}$; skąd $\frac{5}{6} \cdot \frac{91}{216}=\frac{455}{1296}$ wyraża podobieństwo chybienia za pierwszym, i trafienia Asa w następuiących trzech rzutach. Zaczem podobieństwo szukane $\frac{1}{6}+\frac{455}{1296}=\frac{671}{1296}$, Podobieństwo zaś przeciwnego zdarzenia $\frac{625}{1296}$.

Rzecz uwagi godna, że ten ktory chce iedną kością za czterema rzutami wrzucić Asa, ma tę samą korzyść na swoim przeciwniku, iaką ma ten ktory chce wrzucić 6 lub 7 we dwie kości za dwoma rzutami, wobydwoch bowiem przypadkach stósunek losów $=671$ do 625 . skąd nie iest trudno determinować [str. 7] zysk iedney strony z wyższości przypadków które ma nad swego przeciwnika, przypuściwszy że ich wstawka iest równa i naznaczona iednoscią. I lubo to iest tylko szczególny przykład prawidła podanego w $\S .3$, przecież nie zaszkodzi przypomnieć ie sobie. Niech będzie $\frac{a}{b}$ stósunkiem losów, Podobieństwa trafu względem graiących są $\frac{a}{a+b}, \frac{b}{a+b}$, prawo pierwszego do wstawki drugiego $=\frac{a}{a+b} \times 1$, i podobnie prawo drugiego do wstawki pierwszego $=\frac{b}{a+b} \cdot 1$, korzyść pierwszego w grze iest $\frac{a-b}{a+b} \cdot 1=\frac{a-b}{a+b}$. 
Korzyść więc tego który przedsiębierze 6 albo 7 wrzucić w dwoch rzutach dwoch kości, albo ktory zakłada sobie wrzucenie Asa w czterech rzutach kości, iest $\frac{671-625}{671+625}=\frac{46}{1296}$ to iest blisko $\frac{1}{28}$ część wstawki swego przeciwnika.

Przykład IV. Wynaleśdź podobieństwo trafu na wrzucenie dwóch Asow w dwoch rzutach iedney kości.

$\mathrm{Z}$ rozumowania i prawidła podanego $\mathrm{w} \S .4$. oczywiście wypada że $\frac{1}{6} \cdot \frac{1}{6}=\frac{1}{36}$ iest podobieństwem szukaném.

Przykład V. Jakie iest podobieństwo trafu na wrzucenie dwoch asów za trzema rzutami iedney kości?

Wrzuciwszy asa za pierwszym razem, trzeba go ieszcze wrzucić raz w dwoch ostatnich rzutach, aże Podobieństwo wrzucenia go za pierwszym razem $=\frac{1}{6}$, a Podobieństwo wrzucenia go raz $\mathrm{w}$ dwóch rzutach podług Przyk. I $=\frac{11}{36}$ więc Podobieństwo wrzucenia go w pierwszym rzucie, i znowu wrzucenia go $\mathrm{w}$ raz $\mathrm{w}$ dwoch ostatnich rzutach $=\frac{1}{6} \cdot \frac{11}{36}=\frac{11}{216}$, to iest pierwszą częścią podobieństwa szukanego.

Chybiwszy asa za pierwszym rzutem, wypada wypada go wrzucić w dwoch ostatnich rzutach dwa razy, aże podobieństwo chybienia go $\mathrm{w}$ pierwszym $=\frac{5}{6}$, a podobieństwo wrzucenia go dwa razy $\mathrm{w}$ dwoch rzutach podług Przykł. IV. $=\frac{11}{36}$, więc podobieństwo chybienia go pierwszy raz a trafienia dwa razy $\mathrm{w}$ dwoch rzutach $=\frac{5}{6} \cdot \frac{1}{36}=\frac{5}{216}$ to iest $2^{\underline{g a}}$ część podobieństwa szukanego, więc podobieństwo szukane $\frac{11+5}{216}=\frac{16}{216}$. Podobieństwo przeciwnego zdarzenia $=\frac{200}{216}$.

Przykład VI. Jakie iest podobieństwo wrzucenia dwoch asów w czterych rzutach iedney kości?

Podobieństwo wrzucenia asa pierwszy raz $=\frac{1}{6}$, ale trafiwszy pierwszy raz wypada ieszcze trafić raz w trzech rzutach na co mamy z Przykładu II Podobieństwo trafu $=\frac{91}{216}$, więc że się oboie zdarzy iest podo-

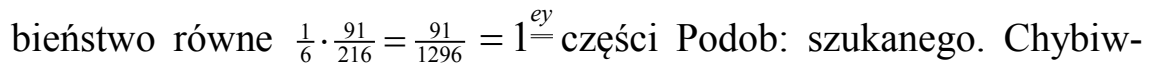
szy asa pierwszy raz na co podobieństwo $=\frac{5}{6}$, wypada go wrzucić dwa razy w trzech rzutach ostatnich na co podobieństwo z Przykładu 
$\mathrm{V} .=\frac{16}{216}$; więc że się oboie trafi podobieństwo równe $\frac{5}{6} \cdot \frac{16}{216}=\frac{80}{1296}, 2^{\underline{\underline{g a}}}$

część podobieństwa szukanego a przeto Podobieństwo szukane $\frac{91}{1296}+\frac{80}{1296}=\frac{171}{1296}$. Tym samym sposobem rozumuiąc znaydziemy następnie Podobieństwo wrzucenia Asa tyle razu ile nam się podoba, w iakiéykolwiek liczbie daney rzutów.

[Rachunek Losów: str. 8]

[na lewym marginesie: wzory ogólne na wynalezienie podobieństwa trafu]

§.7. Używaiąc liter do wyrażenia dopiero wymienionych reguł, nazwieymy $a$ liczbę przypadków trafu, $b$ liczbę przypadków chybienia, że zdarzenie iakie trafi się raz w liczbie $n$ doświadczeń, podobieństwo trafu okaże nam szereg

$$
\begin{aligned}
& \frac{a}{a+b}+\frac{a b}{(a+b)^{2}}+\frac{a b^{2}}{(a+b)^{3}}+\frac{a b^{3}}{(a+b)^{4}}+\frac{a b^{4}}{(a+b)^{5}}+\& c= \\
& =\frac{a}{a+b}\left[1+\frac{b}{a+b}+\frac{b^{2}}{(a+b)^{2}}+\frac{b^{3}}{(a+b)^{3}}+\frac{b^{4}}{(a+b)^{4}}+\& c\right]
\end{aligned}
$$

ktory to szereg należy ciągnąc do tyla terminów, poki ich liczbanie będzie równa liczbie $n$ doświadczeń. I tak ieżeli $a=1, b=5$, liczba doświadczeń n.p. rzutów $n=4$, podobieństwo trafu będzie $=\frac{1}{6}+\frac{5}{36}+\frac{25}{216}+\frac{125}{1296}=\frac{671}{1296}$ : tak iak w przykł. III.

Też same zachowuiąc przypuszczenia, że los iaki zdarzy się dwa razy w liczbie $n$ iakieykolwiek doświadczeń, podobieństwo trafu wyraża się przez szereg

$$
\begin{gathered}
\frac{a^{2}}{(a+b)^{2}}+\frac{2 a^{2} b}{(a+b)^{3}}+\frac{3 a^{2} b^{2}}{(a+b)^{4}}+\frac{4 a^{2} b^{3}}{(a+b)^{5}}+\frac{5 a^{2} b^{4}}{(a+b)^{6}}+\& c= \\
=\frac{a^{2}}{(a+b)^{2}}\left[1+\frac{2 b}{a+b}+\frac{3 b^{2}}{(a+b)^{2}}+\frac{4 b^{3}}{(a+b)^{3}}+\& c\right]
\end{gathered}
$$

ktory to szereg należy ciągnąć do liczby terminów $n-1$, to iest o iedność mnieyszey od liczby $n$ doświadczeń. Niech będzie $a=1$, $b=5, n=8$. Podobieństwo trafu

$$
=\frac{1}{36}+\frac{10}{216}+\frac{75}{1296}+\frac{500}{7776}+\frac{3125}{46656}+\frac{18750}{279936}+\frac{109375}{1679616}=\frac{663991}{1.679 .616} .
$$


I znowu że los iaki wypadnie trzy razy w liczbie $n$ doświadczeń, podobieństwo trafu wyraża się

$$
\begin{gathered}
\frac{a^{3}}{(a+b)^{3}}+\frac{3 a^{3} b}{(a+b)^{4}}+\frac{6 a^{3} b^{2}}{(a+b)^{5}}+\frac{10 a^{3} b^{3}}{(a+b)^{6}}+\frac{15 a^{3} b^{4}}{(a+b)^{7}} \& c= \\
=\frac{a^{3}}{(a+b)^{3}}\left[1+\frac{3 b}{a+b}+\frac{6 b^{2}}{(a+b)^{2}}+\frac{10 b^{3}}{(a+b)^{3}}+\& c\right]
\end{gathered}
$$

który to szereg należy ciągnąć do liczby terminów $n-2$, ieżeli $n$ wyraża liczbę rzutów czyli doświadczeń.

Te wszystkie szeregi podobieństwo trafu wyrażaiące na traf losu raz, dwa, trzy, 1. razy w liczbie $n$ doświadczeń, zamknąć możemy w iednym szeregu ogólnym: Niech $a$ oznacza liczbę przypadków trafu, $b$ liczbę przypadków chybienia, $l$ liczbę razy ile powinien los wypasdz, $n$ liczbę doświadczeń, położmy $a+b=s$ : że los wypadnie 1 razy w liczbie $\mathrm{n}$ doświadczeń Podobieństwo trafu iest $=$

$$
\frac{a^{l}}{s^{l}}\left[1+\frac{l b}{s}+\frac{l \cdot(l+1) b^{2}}{1 \cdot 2 \cdot s^{2}}+\frac{l \cdot(l+1)(l+2) b^{3}}{1 \cdot 2 \cdot 3 \cdot s^{3}}+\frac{l \cdot(l+1)(l+2)(l+3) b^{4}}{1 \cdot 2 \cdot 3 \cdot 4 \cdot s^{4}}+\& c\right] \text {. }
$$

s którego to szeregu należy wziąć terminów początkowych liczbę $n-l+1$, a Zbiór ich wyrażać będzie podobieństwo trafu szukane.

Chcąc teraz znaleśdz podobny wyraz ogólny okazuiący podobieństwo chybienia, to iest że los nie trafi się $l$ razy w liczbie $n$ doświadczeń trzeba nam teraźnieysze zadanie przywiesdź do poprzedzaiącego, czego dokażemy przez następuiącą uwagę. Wystawmy sobie dwoch graczow, $A$, i $B$, ubiegaiących się przez Zakłady o wygraną: liczba przypadków trafu dla $A$ iest $a$, a liczba podobnych przypadków dla $B$ iest $b ; A$ utrzymuie że los wypadnie $l$ razy w liczbie $n$ doświadczeń; $B$ utrzymuie że nie wypadnie $l$ razy w $n$ doświadczeniach, więc ieżeli los wypadnie tylko $l-1$ razy w $n$ doświadczeniach, $B$ wygra: od $n$ odciągnąwszy $l-1$, czyli $n-l+1$ pokazuie że ieżeli los wypadnie $n+1-l=n-l+1$ razy w liczbie $n$ doświadczeń, $B$ wygra; ieżeli zaś wypadnie $l$ razy w teyże samey liczbie $n$ doświadczeń, $A$ wygrywa: szukaiąc podobieństwa trafu dla $B$ którego przypadki przyiazne są $b$, a nieprzyiazne $a$; to podobieństwo wypadnie $\mathrm{z}$ rozwiązania następuiącego zagadnienia: maiąc $b$ liczbę przypadków trafu, liczbę przypadków chybienia $a$, znaleśdz podobieństwo trafu, że los wypadnie $n-l+1$ razy w liczbie $n$ doświadczeń? Nazwawszy $n-l+1=p$, 
widzemy oczywiście że szereg (1), który wyrażał podobieństwo trafu dla $A$, położywszy w nim za $l, p$; za $b, a$; za $a, b$; wyrażać będzie

Nr 13(19)

$\frac{b^{p}}{s^{p}}\left[1+\frac{p a}{s}+\frac{p \cdot(p+1) a^{2}}{1 \cdot 2 \cdot s^{2}}+\frac{p \cdot(p+1)(p+2) a^{3}}{1 \cdot 2 \cdot 3 \cdot s^{3}}+\frac{p \cdot(p+1)(p+2)(p+3) a^{4}}{1 \cdot 2 \cdot 3 \cdot 4 \cdot s^{4}}+\& c\right]$ podobieństwo chybienia dla $A=$

[Rachunek Losów: str. 9]

s którego to szeregu należy wziąc terminów początkowych liczbę $l$, a ich zbiór okaże podobieństwo chybienia, to iest że los nie wypadnie $l$ razy w liczbie $n$ doświadczeń. Powiedziałem że należy wziąć liczbę $l$ terminów z szeregu (2); bo tu $n$ wyraża liczbę doświadczeń, $n-l+1$ liczbę razy ile los wypaśdź powinien, więc liczba terminów do wzięcia bydź powinna $=n-(n-l+1)+1=l$.

Powiedzieliśmy wyżey, że podobieństwo trafu dodane do podobieństwa chybienia daie iedność, więc maiąc znane podobieństwo chybienia, poznamy natychmiast podobieństwo trafu: możemy przeto używać szeregu (1), albo szeregu (2) do rozwiązania zagadnień trzymaiąc się atoli zawsze tego, w którym rachunek zachodzi krótszy i łatwieyszy. Aże używaiąc szeregu (1) należy nam z niego wziąc terminów liczbę $n-l+1$; używaiąc zaś (2) potrzeba wziąć terminów liczbę $l$, więc dla krotszego rachunku ieżeli $n-l+1<l$ czyli $\frac{n+1}{2}<l$ należy użyć szeregu (1); ieżeli zaś $\frac{n+1}{2}>l$, należy użyć szeregu (2). I tak wystawmy sobie los maiący ieden przypadek trafu a 35 przypadków chybienia, gdybyśmy chcieli znaleśdź podobieństwo trafu na zdarzenie się tego losu raz w 24 doswiadczeniach, ponieważ tu $n=24$, $l=1, b=35, a=1$, na wynalezienie podobieństwa trafu musieli byśmy wziąc 24 terminy używaiąc (1) szeregu, kiedy używaiąc szeregu ostatniego (2) nie potrzeba nam tylko iednego terminu, i podobieństwo chybienia $=\frac{35^{24}}{36^{24}} \cdot 1$. ktorego ułomku przez Logarytmy znaleziona wartość $=0,50871$, co odciągnąwszy od iedności reszta da podobieństwo trafu $=0,49129$ a zatem stosunek losów że chybi będzie blisko 50 do 49 . - Podobnie gdyby nam przyszło szukać podobieństwa trafu, że tenże sam los co przedtym wypadnie dwa razy w 60 doświadczeniach, będzie $l=2, n=60, n-l+1=59$, co pokazuie, żeby nam trzeba wziąć 59 terminów używaiąc szeregu (1), kiedy używaiąc drugiego nie potrzeba brać tylko dwa terminy, i będzie po- 
dobieństwo chybienia $\frac{35^{59}}{36^{59}}\left[1+\frac{59}{36}\right]=0,5007$ co ociągnąwszy od ied- $\begin{aligned} & \text { STATYSTYCZNY } \\ & \mathrm{Nr} \text { 13(19) }\end{aligned}$ ności, otrzymamy podobieństwo trafu $=0,4993$ a zatem stosunek losów za zdarzeniem iest blisko 499 do 500.

Przykład VII. Znalesdź podobieństwo trafu na wrzucenie Asa raz tylko a nie więcey, w czterech rzutach kości.

To zadanie należy dobrze rozróżnić od przykładu III, tam bowiem w iakimkolwiek z czterech rzutów wypadł As, gra ustaie; tu zaś przez warunek położony, wrzuciwszy asa w pierwszym n. p. rzucie, obowiązany iest gracz do dalszych rzutów które są całkiem przeciwko Niemu aż do ostatniego rzutu po którym gra ustaie. W Przykładzie

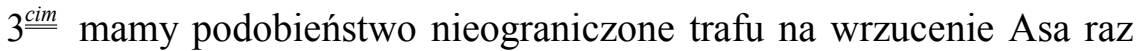
lub więcey w czterech rzutach $\frac{671}{1296}$; w Przykładzie VI $\stackrel{\text { tym }}{=}$ mamy podobieństwo trafu na wrzucenie dwa razy przynaymniéy, a zatem i więcey razy Asa za czterema rzutami $=\frac{171}{1296}$ : odciągnąwszy drugie od pierwszego, zostaie się $\frac{500}{1296}$. Podobieństwo trafu na wrzucenie raz tylko a nie więcey Asa w czterech rzutach. Podobieństwo zaś [Rachunek Losów: str. 10] chybienia $=\frac{796}{1296}$; stósunek losów przeciwko wygrany 796 do 500, to jest blisko 8 do 5 .

Przykład VIII. Niech będzie dwóch graczów $A$, i $B$ razem graiących. Gracz $A$ potrzebuie iednego, Gracz zaś $B$ potrzebuie dwóch punktów do skończenia gry całéy i do wygraney. Jakież będzie dla każdego z nich podobieństwo do wygrany?

Tu zważyć nam nasamprzód potrzeba że cała gra skończy się zrobieniu naywięcey dwoch punktów, a ieżeli każdy punkt potrzebuie iedney gry, więc wygrana zupełna będzie po dwóch naywięcey grach, gdyż ieżeli za pierwszą grą $A$ zrobi punkt ieden, cała wygrana skończy się: ieżeli zaś ten punkt zrobi gracz $B$, więc każdemu z nich nie będzie brakować tylko iednego punktu, który gdy za drugą grą musi wypaśdź dla $A$ lub $B$, cała wygrana skończyć się musi: z czego to się okazuie, że gracz $A$ potrzebuie raz tylko, gracz zaś $B$ potrzebuie dwa razy wygrać, w dwoch tylko grach: A ieżeli obydwa gracze są w zupełnie równych okolicznościach do wygrania lub chybienia pierwszy gry, więc podług §.2. podobieństwo trafu że $B$ wygra pierwszą grę $=\frac{1}{2}$, a zatem że wygra dwa razy tuż po sobie Podobieństwo trafu $=\frac{1}{2} \cdot \frac{1}{2}=\frac{1}{4}$; 
a zatem podobieństwo trafu że $A$ wygra $=1-\frac{1}{4}=\frac{3}{4}$, stósunek losów Nr 13(19) za wygraną $A$ iest, iak 3 do 1.

Przykład IX. Dway gracze $A$, i $B$ graiąc z sobą, $A$ potrzebuie iednego punktu, $B$ zaś potrzebuie ich dwa do skończenia całey gry i zupełney wygraney; ale $B$ ma za sobą dwa razy więcey przypadków trafu iak $A$ : iakież dla każdego z nich będzie podobieństwo wygrany?

Widzemy to iak w poprzedzaiącym przykładzie że cała wygrana okaże się po dwóch grach, w których potrzeba dla $B$ dwa razy, a zaś $A$ raz tylko wygrać: ponieważ zaś $B$ ma dwa przypadki do wygrania iedney gry, a $A$ ma ich tylko ieden: więc podobieństwo że $A$ wygra pierwszy raz $=\frac{2}{3}$, a zatem że wygra dwa razy tuż po sobie iest podobieństwo trafu $=\frac{2}{3} \cdot \frac{2}{3}=\frac{4}{9}$, a zatem podobieństwo trafu dla $A=1-\frac{4}{9}=\frac{5}{9}$. Stósunek losów że $A$ wygra raz nim $B$ wygra dwa razy, iest iak 5 do 4 .

Tu wypada nam zrobić bardzo potrzebną uwagę: Bardzo iest niebezpieczno $\mathrm{w}$ materyach losu wnioskować $\mathrm{z}$ powierzchownego widzenia rzeczy i rozumować bez pomocy rachunku: w ostatnim przykładzie zdaie się z warunków Pytania obydwoch Graczy podobieństwo równe do wygrany atoli oczywiście rachunek pokazał nie równość, którą to nierówność przez rachunek odkrytą można zastanowiwszy się znaleśdź przez rozumowanie: gdyż lubo $B$ ma dwa razy więcey przypadków trafu iak $A$, to tylko pokazuie iż ciągnąc grę częściéy można wygrawać $B$ iak $A$; ale tu w dwóch grach potrzeba obydwie wygrać $B$, a tylko iednę $A$, przypadek zaś trafu nie iest to iedno co pewna wygrana iakiéy to potrzeba, a zatem z tego względu losy dla $B$ i $A$ nie są tu zupełnie równe.

8. Jakakolwiek iest liczba grów, którey dwa gracze $A$ i $B$ potrzebuią do skończenia losu i otrzymania wygrany; t wygrana skończy się naydaléy po takiéy liczbie grów iaka wypadnie odciągnąwszy jedność od Summy grów których każdy z nich do wygrany potrzebuie. [str. 11]

Wystawmy sobie n. p. że $A$ potrzebuie 3 punktów albo grów do wygrany i skończenia całey gry; $B$ zaś potrzebuie podobnych grów lub punktów 5: cała wygrana skończyć sie naypóźniey musi po liczbie grów $5+3-1=7$; albowiem nim przyidzie do ostatniey determinacyi gry i wygrany całey, $A$ musi mieć koniecznie 2 gry za sobą, $B$ zaś musi ich mieć 4, po których iedna gra kończy wszystko dla $A$ ieżeli będzie na iego stronę, lub dla $B$ ieżeli ią $B$ wygra, a zatem wszystko do skończenia potrzebuie naywięcey 7 grów. Przez podobne rozumowanie okazać można tę prawdę w innych przypadkach. 
Przykład X. Gracz $A$ potrzebuie 3 punktów do skończenia całey gry i wygrany; gracz zaś $B$ potrzebuie ich 7; ale liczby przypadków trafu iakie zachodzą między $A$ i $B$ są w stósunku iak 3 do 5. Jakież dla STATYSTYCZNY każdego podobieństwo wygrany, i jaki stosunek losów?

Tu wystawiamy sobie że otrzymanie punktu wyciąga koniecznie iedney gry, więc gdy obydwa gracze potrzebuią 10 grów, cała wygrana skończy się naydaley po 9 grach: w których to 9 grach $A$ potrzebuie trzy razy wygrać, $B$ zaś siedm razy: Stosuiąc do teraźniéyszego przykładu szeregi (1), (2), dane pod §.7, gdybyśmy chcieli użyć szeregu (1) do znalezienia Podobieństwa wygrany dla $A$, mielibyśmy $l=3$, $n=9$, ale liczba terminów do wzięcia $\mathrm{z}$ szeregu (1) byłaby $n-l+1=7$; kiedy używaiąc szeregu drugiego na znalezienie podobieństwa wygrany dla $B$, mamy $n=9 ; l=3 ; a=3 ; b=5$ liczba terminów do wzięcia $l=3$; Podobieństwo wygrany dla $B$ $=\frac{5^{7}}{8^{7}}\left[1+\frac{21}{8}+\frac{252}{64}\right]=\frac{5^{7}}{8^{9}} \cdot 484=0,28172$ blisko, co odciągnąwszy od iedności wypada Podobieństwo wygrany dla $\mathrm{A}=0,71828$. Stósunek losów za wygraną A iest 71828 do 28172 to iest blisko iak 23 do 9.

[na prawym marginesie: Inny sposób rozwiązania wszystkich poprzedzaiących Pytań]

9. Wyłożone dotąd początki i prawidła służyć mogą do rozwiązania wielu pytań o losie: lubo zaś są prostym i iasnym sposobem te początki wyłożone, atoli mogą bydź ieszcze innym sposobem dowiedzione i prawie wyciągnione z uwagi nad iednym ogólnym wzorem.

Wystawmy sobie kość iakiey zwyczainie do gry używaią, maiącą pewną iakąkolwiek liczbę ścian równych; powtóre wystawmy sobie drugą kość maiącą tęż same co pierwsza, lub inną iakąkolwiek liczbę ścian także równych: wszystkie odmiany które tylko w rzucie i grze tych dwóch kości zachodzić mogą zamknięte są w mnogości która powstaie mnożąc liczbę ścian pierwszey kości przez liczbę ścian kości drugiey.

Na dowód tey prawdy niech będzie kość pierwsza maiąca ośm scian równych, kość zaś druga maiąca tych że ścian równych dwanaście: ustawiwszy iednę pewną ścianę kości pierwszéy, z nią łączyć możemy wszystkie dwanaście ścian kości drugiéy: po czym ustawiwszy znowu drugą ścianę kości pierwszey, z nią znowu układać możemy wszystkie dwanaście ścian kości drugiéy, co nam iuż daie dwa razy dwanaście kombinacyi dwóch kości: toż samo czyniąc z trzecią, czwartą i. t. d. ścaną kości pierwszéy, i z każdą z nich układaiąc dwa- 
naście ścian kości drugiey za każdą razą otrzymamy nowych dwanaście odmian, a zatem wszystkich odmian zachodzących tyle razy dwanaście będzie ile ścian zamyka kość pierwsza: to iest tyle ile wynosi mnogość powstaiąca $\mathrm{z}$ rozmnożenia liczby ścian w kości pierwszey [str. 12] przez liczbę ścian kości drugiéy $12 \cdot 8=96$. Stego szczególnego przykładu widzieć możemy sposób dowodzenia tey prawdy na wszystkie iakiekolwiek przypadki dwóch kości, i przekonania się o ogólney prawdzie założonéy.

Przybrawszy sobie kość trzecią, każda kombinacya dwóch pierwszych kości układać się może z każdą ścianą kości trzeciéy, a zatem rozmnożywszy liczbę odmian zachodzących w dwóch kościach przez liczbę ścian trzeciey, otrzymamy liczbę odmian które zachodzą w grze trzech kości.

Wziąwszy znowu kość czwartą z iakąkolwiek liczbą ścian, każda kombinacya trzech kości układać się może z każdą ścianą czwartey kości, i znowu liczba odmian w czterech kościach rowną będzie mnogości powstaiącey z z rozmnożenia przez siebie czterech liczb odpowiadaiących liczbie ścian czterech kości. Zgoła niech będzie iaka kolwiek liczba kości, a każda kość niech ma iakąkolwiek liczbę ścian równych. Wziąwszy liczbę ścian w każdey szczególności kości, i te wszystkie potym liczby rozmnożywszy przez siebie, otrzymamy w mnogości liczbę odmian zachodzić mogących w grze wszystkich tych kości.

10. Wróćmy się teraz do uwagi dwóch tylko kości, i wystawmy sobie dwoiakie ściany w każdéy, białe i czarne; kość pierwsza ma ścian białych liczbę $A$, ścian czarnych liczbę $B$ : kość znowu druga ma ścian białych liczbę $a$, ścian czarnych liczbę $b$; liczba ścian wszystkich w pierwszey kości $A+B$ : liczba ścian wszystkich w drugiéy $=a+b ;$ a zatem liczba wszystkich odmian $\mathrm{w}$ obydwóch kościach $=(A+B)(a+b)=A a+A b+B a+B b$, w tych czterech terminach mamy następuiące znaczenia:

Naprzód Jako mnogość z liczby scian pierwszey, przez liczbę scian drugiéy kości wyraża wszystkie odmiany obydwoch kości; tak liczba ścian białych w pierwszey przez liczbę scian białych w drugiéy kości wyraża wszystkie odmiany zachodzące w scianach białych obydwoch kości, a zatym termin $A a$ zamyka liczbę przypadkow trafu na wrzucenie w grze dwoch kości obydwoch scian białych.

Powtóre przez podobne rozumowanie łatwo się przekonać że liczba ścian białych pierwszey rozmnożona przez liczbę ścian czarnych drugiey kości, okaże liczbę przypadków w grze dwóch kości tak uło- 
żonych, aby kość pierwsza padła na białą a kość druga na czarną scianę: a zatem termin $A b$ wyraża liczbę przypadków trafu na wrzucenie iakieykolwiek ściany białey $\mathrm{w}$ pierwszey, i iakieykolwiek sciany STATYSTYCZNY czarney w drugiéy kości.

Potrzecie Termin $B a$ wyraża liczbę przypadków trafu na wrzucenie iedney ściany czarney w pierwszey, i iedney ściany białey w drugiéy kości, a zatem Summa terminów $A b+B a$ wyraża liczbę przypadków trafu na wrzucenie iedney białey, a drugie czarney ściany w iakieykolwiek kosci.

Poczwarte Termin $B b$ wyraża liczbę przypadków wszystkich trafu na wrzucenie obydwoch ścian czarnych przez dwie kości.

Wythumaczone dopiero znaczenie terminów okazuie nam że te służą nam do odpowiedzi na pytania wszystkie które tylko w grze dwóch kości zachodzić mogą: bo z nich ułożyc można podobieństwo trafu na każdy przypadek.

$\frac{A a}{A a+A b+B a+B b}=$ Podobieństwo trafu, żeby koniecznie wrzucić dwie ściany białe.

$\frac{B b}{A a+A b+B a+B b}=$ Podob: trafu żeby wrzucić obydwie ściany czarne. [Rachunek Losów: 13]

$\frac{A a+A b+B a}{A a+A b+B a+B b}=$ Pod. trafu żeby wrzucić przynaymniéy iednę ścianę białą, gdzie nawet dwie ściany białe nie przegrywaią.

$\frac{A b+B a+B b}{A a+A b+B a+B b}=$ Pod. trafu żeby wrzucić przynaymniéy iednę ścianę czarną.

$\frac{A b+B a}{A a+A b+B a+B b}=$ Podobieństwo trafu, żeby wrzucić iednę tylko ścianę białą, albo iednę tylko ścianę czarną.

Przybierzmy sobie teraz kość trzecią z iakąkolwiek liczba ścian, $\mathrm{w}$ niéy liczba ścian białych $=\alpha$, liczba ścian czarnych $=\beta$, liczba ścian wszystkich $=\alpha+\beta ;(A a+A b+B a+B b)(\alpha+\beta)=$ $A a \alpha+A b \alpha+B a \alpha+B b \alpha+A a \beta+A b \beta+B a \beta+B b \beta$ wyraża liczbę wszystkich odmian zachodzić mogących w grze trzech kości.

Roztrząsaiąc terminy tey mnogości, poznamy łatwo: że termin pierwszy $A a \alpha$ wyraża liczbę przypadków trafu na wrzucenie wszystkich trzech ścian białych; termin drugiéy $A b \alpha$ liczbę przypadków trafu na wrzucenie dwóch ścian białych to iest pierwszey i trzeciéy, a 
iedney ściany czarney w drugiéy kości i tak daley, co proste przypatrzenie się każdego nauczy. Biorąc zatem po iednym lub po kilka terminów takowéy mnogości, mamy odpowiedź na iakie pytanie ktore zachodzi w grze trzech kości. Nie tylko zaś terminy przypadki trafu wyrażaiące przywiodą nas do podobieństwa trafu, ale ieszcze reszta terminów od mnogości pozostałych daie liczbę przypadków chybienia, sktórey łatwo mieć i podobieństwo chybienia i stósunek losów. I tak n. p. na zapytanie iaka iest liczba przypadków trafu na wrzucenie dwóch ścian białych a iedney czarney przez trzy kosci? daią odpowiedź terminy $A b \alpha+B a \alpha+A a \beta$ : i ten który się zakłada na zdarzenie tego losu, ma za soba stósunek losów $A b \alpha+B a \alpha+A a \beta$ do $A a \alpha+B b \alpha+A b \beta+B a \beta+B b \beta$ gdyż ostatnie pięć terminów to iest reszta mnogości od pozostałey liczby trafów, wyraża liczbę przypadków chybienia.

Ponieważ Aa $\alpha$ wyraża liczbę przypadków trafu na wrzucenie trzech ścian białych, więc podobieństwo trafu

$$
\begin{aligned}
& =\frac{A a \alpha}{A a \alpha+A b \alpha+B a \alpha+B b \alpha+A a \beta+A b \beta+B a \beta+B b \beta} \\
& =\frac{A a \alpha}{(A+B)(a+b)(\alpha+\beta)}=\frac{A}{A+B} \times \frac{a}{a+b} \times \frac{\alpha}{\alpha+\beta} \text {; aże w tey ostatniey }
\end{aligned}
$$

funkcyi pierwszy mnożnik wyraża podobieństwo trafu na wrzucenie pierwszą kością ściany białey: trzeci Mnożnik takież podobieństwo wyraża na wrzucenie trzecią kością ściany białey; więc stąd okazuie się prawda tego prawidła któreśmy podali w §.4. iż Podobieństwo trafu na wiele zdarzeń i losów niezawisłych wypadnie z rozmnożenia ułomków wszystkich wyrażaiących podobieństwo trafu na każdy los poiedyńczy: bo lubo przykład teraźnieyszy nie zachodzi tylko między trzema zdarzeniami, łatwo atoli stąd widzieć prawdę reguły powszechney na iakąkolwiek liczbę zdarzeń niezawisłych.

Weźmy się ieszcze do przykładu dwóch kości, sktórych pierwsza ma liczbę ścian białych $A$, liczbę ścian czarnych $B$, liczbę ścian wszystkich $A+B$; druga liczbę ścian białych $a$, scian czarnych $b$, ścian wszystkich $a+b$ : [str. 14] mnogość $A a+A b+B a+B b$ zamyka liczbę wszystkich odmian zachodzić mogących w grze dwoch kości: przypuśćmy teraz że liczba ścian w obydwoch kościach iest zupełnie równa, i że tyle iest białych ścian na pierwszey ile na drugiéy, podług takiego przypuszczenia $A=a, B=b$, a więc szukana mnogość zamieni się na $a^{2}+2 a b+b^{2}$, w którey $a^{2}$ wyraża liczbę przypadków trafu na wrzucenie dwoch ścian białych; $b^{2}$ takąż liczbę na wrzucenie 
dwóch ścian czarnych, $2 a b$ liczbę przypadków trafu na wrzucenie iedney ściany białey i iedney czarney. Podobnie zważaiąc przykład trzech kości i we wszystkich równa ścian liczbę będzie $A=a=\alpha$, $B=b=\beta$, mnogość z trzech mnożników powstaiąca zamieni się na $(a+b)^{3}=a^{3}+3 a^{2} b+3 a b^{2}+b^{3}, A a \alpha=a^{3}$ wyraża liczbę przypadków trafu na wrzucenie trzech ścian białych, $A b \alpha+B a \alpha+A a \beta=3 a^{2} b$ przypadki trafu na wrzucenie dwóch ścian białych a iedney czarney.

11. Stey ostatniéy uwagi wypada ogólne prawidło: Niech będzie iakakolwiek liczba $n$ kości maiących równą liczbę ścian, podzielonych na białe i czarne, niech liczba ścian białych na każdey kości będzie $=a$, liczba ścian czarnych na każdey $=b$, wyniosłszy funkcyą dwuwyrazową do potęgi $n$, to iest $(a+b)^{n}$ : w tey Naprzod pierwszy termin $a^{n}$ wyraża liczbę przypadków trafu na wrzucenie $n$ ścian białych. Powtóre drugi termin $n a^{n-1} b$, liczbę przypadków trafu na wrzucenie ścian białych liczbę $n-1$, i iedney czarney: Potrzecie termin trzeci $n \cdot \frac{n-1}{2} a^{n-2} b^{2}$ wyraża liczbę trafów na wrzucenie $n-2$ ścian ścian białych i dwóch czarnych i td. ogólnie wykładnik $a$ wyrażać będzie liczbę ścian białych, wykładnik zaś $b$ liczbę ścian czarnych wrzucić się mogąca.

Zebyśmy mogli porównać prawidła wypadaiące $\mathrm{z}$ uwagi funkcyi dwuwyrazowéy wyniesioney do Potęgi $n$, gdzie $n$ znaczy liczbę kości; z prawidłami wyżey iuż podanemi weźmy do rozwiązania Pytania, naktóreśmy iuż w $\S$. 6. dali odpowiedź.

Znaleśdź Podobieństwo trafu na wrzucenie Asa w czterech rzutach kości iednéy sześć ścian maiącey?

Chcąc odpowiedzieć na to Zapytanie potrzeba nam zauważyć, że rzucać cztery razy iednę kość, czyli też rzucić razem cztery kości równe i podobne wszystko iedno znaczy, bo tu różnica cała zachodzi w czasie który bynaymniéy w wypadek losu nie wpływa: iak prędko bowiem liczba przypadków trafu i chybienia zostaie ta sama, czas dłuższy lub krótszy potrzebny do gry bynaymniéy losu nie odmienia: a zatem pytanie zadane może się inaczey tak wyłożyć: znaleśdź podobieństwo trafu na wrzucenie Asa za iednym rzutem czterech kości. W takim znaczeniu niech As wyznacza to, cośmy nazwali ściany białe; ściany zaś czarne niech znaczą wszystkie inne punkta na kości oprócz Asa, a przeto $a=1, b=5$, wyniosłszy $a+b$ do potęgi czwartey $a^{4}+4 a^{3} b+6 a^{2} b^{2}+4 a b^{3}+b^{4}$ : Summa terminów 
$a^{4}+4 a^{3} b+6 a^{2} b^{2}+4 a b^{3}$, w których każdym znayduie się $a$, wyrażać

Nr 13(19) będzie liczbę przypadków trafu $=1+20+150+500=671$, potęga zaś czwarta $(1+5)^{4}=1296$ wyraża liczbę przypadków wszystkich, więc podobieństwo szukane $=\frac{671}{1296}$. Podobieństwo co się zupełnie zgadza z Przykł: III.

Gdybyśmy byli szukali podobieństwa chybienia, rachunek wypada krótszy bo to $=\frac{b^{4}}{(a+b)^{4}}=\frac{625}{1296} ;$ skąd $1-\frac{625}{1296}=\frac{671}{1296}$ Podobieństwo trafu.

Ogólnie rozwiązuiąc zadanie: ażeby w rzucie kości n, lub w rzutach n kości iedney trafi na Asa. Podobieństwo chybienia to iest żeby żaden As nie wypadł iest $=\frac{b^{n}}{(a+b)^{n}}$ a zatem podobieństwo trafu $=1-\frac{b^{n}}{(a+b)^{n}}=\frac{(a+b)^{n}-b^{n}}{(a+b)^{n}}$, ostatni bowiem termin potęgi [str. 15] dwuwyrazowéy nie zamyka a, a zatem wyraża liczbę przypadków na chybienie Asa.

Podobnym sposobem zadawszy sobie pytanie aby w czterech rzutach iedney kości wrzucić dwa Asy, to pytanie zupełnie iest to samo co za iednym rzutem czterech kości wrzucenie dwóch Asów, a zatem $(a+b)^{4}$, wziąwszy stey funkcyi wszystkie terminy gdzie $a$ iest wyniesione do potęgi drugiey lub wyższey, zbiór ich da liczbę przypadków trafu to iest $a^{4}+4 a^{3} b+6 a^{2} b^{2}=1+20+150=171$. Podobieństwo trafu $=\frac{171}{1296}$, Podobieństwo chybienia $=\frac{4 a b^{3}+b^{4}}{(a+b)^{4}}=1-\frac{171}{1296}=\frac{1125}{1296}$.

Ogólnie chcąc za rzutem iakieykolwiek liczby $n$ kości, lub w rzutach $n$ teyże samey kości wrzucić dwóch Asów, nayłatwiey iest nam znaleśdź Podobieństwo chybienia, bo przypadki chybienia zamykaią się w terminach gdzie się nie znayduie $a$, albo gdzie się tylko znayduie w pierwszy potędze. Aże ta własność w funkcyi $(a+b)^{n}$ służy tylko dwom terminom ostatniemu i przedostatniemu to iest na $n a b^{n-1}+b^{n}$, więc Podobieństwo chybienia dwóch Asów w rzucie $n$ kości $=\frac{n a b^{n-1}+b^{n}}{(a+b)^{n}}$, a stego Podobieństwo trafu $=1-\frac{n a b^{n-1}+b^{n}}{(a+b)^{n}}=\frac{(a+b)^{n}-n a b^{n-1}-b^{n-1}}{(a+b)^{n}}$. 
Chcąc za iednym rzutem $n$ kości, albo w rzutach $n$ iednéy kości wrzucić trzech Asów, łatwo iest determinować podobieństwo chybienia, którego przypadki są zawarte w trzech ostatnich terminach STATYSTYCZNY $(a+b)^{n}$, w nich bowiem $a$ nie znayduie sie w wyższey potędze nad drugą: od tego podobieństwa łatwo przyiśdź do podobieństwa trafu. Podobnie rozumować można o innych przykładach w grze kości: rozwiązuiąc ich Pytania przez własności funkcyi dwuwyrazowey $(a+b)^{n}$, wszystkie wypadki znaydziemy zgodne $\mathrm{z}$ temi któreśmy wyżey w Przykładach rożnych przez inny znaleźli sposób.

12. Te własności funkcyi dwuwyrazowéy w grze kości spostrzeżone, przystósować można do innych gatunków losu, gdzie idzie o trafienie lub chybienie iakiego zdarzenia w iakieykolwiek liczbie razy, byleby przypadki chybienia i trafu w każdym razie czyli doświadczeniu wyrazić przez $b$ i $a$. I tak wystawiwszy sobie dwóch graczów $A, B$ ubiegaiących się o zdarzenie iakiego losu; gdzie $A$ robi zakład że ten los wypadnie $l$ razy, w liczbie $n$ doświadczeń: $B$ zaś zakłada się że tenże los nie wypadnie $l$ razy w teyże samey liczbie doświadczeń: iest zaś w każdem doświadczeniu liczba przypadków trafu $a$; $b$ liczba przypadków chybienia: z funkcyi $(a+b)^{n}$ wziąwszy tyle ostatnich terminów ile $l$ zamyka iedności, ich zbiór da nam liczbę przypadków chybienia we wszystkich doświadczeniach; którą rozdzieliwszy przez $(a+b)^{n}$ otrzymamy podobieństwo chybienia to iest że $B$ wygra.

$\mathrm{Z}$ drugiey strony $B$ zakładaiąc się że $A$ nie wygra $l$ razy w $n$ doświadczeniach, to samo utrzymuie iak gdyby $A$ nie wygrał więcey razy tylko $l-1$; aże liczba wszystkich wygrywaiących i przegrywaiących zdarzeń między $A$ i $B$, iest $n$ przez założenie, bo graią obydwa $n$ razy, więc odciągnąwszy od $n, l-1$, czyli $n-l+1$ okazuie [str. 16] że $B$ przedsiębierze wygrać $n-l+1$ razy w $n$ doświadczeniach. Nazwawszy $n-l+1=p$, rzecz oczywista iż z funkcyi $(a+b)^{n}$ rozebrawszy na terminy, ostatnie terminy $b^{n}+n a b^{n-1}+n \cdot \frac{n-1}{2} a^{2} b^{n-2}$ i t.d których by liczba była $l$, wyrażaią liczbę przypadków w których $B$ wygrywa zakład; pierwsze zaś terminy $a^{n}+n a^{n-1} b+n \cdot \frac{n-1}{2} a^{n-2} b^{2}$ i t.d których liczba iest $p$ pokazuią liczbę przypadków trafu w których $A$ wygrywa zakład a zatém stósunek losów za wygraną $B$, iest iako liczba $l$ ostatnich do liczby $p$ początkowych terminów z funkcyi $(a+b)^{n}$. [na lewym marginesie: Tenże sam początek stósowany do kontynuacyi (dopisane: trwałości) gry] 
PRZEGLASI STATYSTYCZNY

Nr 13(19)

13. Tenże sam początek funkcyi $(a+b)^{n}$ stósować możemy do zagadnień o skończeniu gry, kiedy zupełna wygrana od pewney liczby grów których każdy gracz potrzebuie, zawisła. I tak założywszy że dwa gracze razem graiący $A$ i $B$ potrzebuią do zupełney wygrany pewney liczby grów, to iest $A$ potrzebuie ich liczbę $l ; B$ zaś potrzebuie ich $p$; obydwa razem potrzebuią ich $l+p$; więc cała gra skończy się naydaléy po liczbie $l+p-1$ grów podług §.8: połóżmy ieszcze że $\mathrm{W}$ każdey szczególnéy grze przypadki trafu za wygraną $A$ i $B$ są $\mathrm{w}$ stósunku iak $a$ do $b$; przeto wyniósłszy funkcyą $a+b$ do potęgi $l+p-1$; liczba przypadków w których każdy $\mathrm{z}$ nich wygrać może zupełnie po skończonéy całey grze będzie w stósunku, iako Summa terminów początkowych tylu, ile iedności wyraża $p$, do Summy terminów ostatnich tylu, ile iedności wyraża $l$.

I tak, gdyby do całey wygrany $A$ potrzebował $3, B$ zaś potrzebował 7 grów; a stósunek trafów w każdey szczególney grze za $A, B$ iest iak 3 do 5 ; będzie $l=3, p=7, a=3, b=5, l+p-1=q$, więc $(a+b)^{9}=(3+5)^{9}$, stósunek losów za wygraną $A$ będzie iak 7 pierwszych, do 3 ostatnich terminów potęgi $(3+5)^{9}$. Wziąwszy zaś trzy ostatnie terminy tey potęgi i te rozdzieliwszy przez potęgę całą, wypadnie nam podobieństwo chybienia $A$, albo podobieństwo wygrany dla $B$, ktore odciągnąwszy od iedności, otrzymamy podobieństwo wygrany dla $A$. Ostatnie trzy terminy $(a+b)^{9}$ są $b^{9}+9 a b^{8}+36 a^{2} b^{7}$, które otrzymuiąc wyżey położoną wartość na $a, b$ równe w liczbach $=37.812500:(a+b)^{9}=134.217728$. a zatem Podobieństwo wygrany dla $B=\frac{37812500}{134.278 .728}=\frac{9453125}{33554432}$ co odciągnąwszy od iedności wypadnie Podobieństwo wygrany dla $A=\frac{24101307}{33554432}$, stósunek losów że $A$ wprzód skończy iak $B$, i że $A$ wygra $\frac{24101307}{33554432}$ to iest blisko iako 23 do 9 . co się zupełnie zgadza z przykładem X.

14. Zostaie nam ieszcze do zupełnego porównania sposobów podanych na rozwiązanie zagadnień o losie, Pytanie w którym zakładamy sobie otrzymać pewną determinowaną liczbę trafów, tak dalece, że liczba trafów mniéysza lub większa nad podaną przegrywać musi. takiego rodzaiu [str. 17] Pytania rozwiązuią się przez ieden tylko termin funkcyi $(a+b)^{n}$. n. p. Znaleśdź podobieństwo trafu na wrzucenie 
nie więcey iak iednego tylko Asa za czterema rzutami iedney kości, lub za iednym rzutem czterech kości?

Ponieważ $n$ znaczy liczbę kości do rzutu iednego, lub liczbę rzutów iedney kości; w teraźniéyszém zadaniu $n=4$; $(a+b)^{4}=a^{4}+4 a^{3} b+6 a^{2} b^{2}+4 a b^{3}+b^{4}$; żeby wrzucić za iednym rzutem czterech kości iednego Asa lub więcey, mamy przypadki trafu w terminach $a^{4}+4 a^{3} b+6 a^{2} b^{2}+4 a b^{3}$; żeby zaś $\mathrm{w}$ iednym rzucie czterech kości wrzucić dwóch Asów lub więcey, terminy $a^{4}+4 a^{3} b+6 a^{2} b^{2}$ dadzą nam przypadki trafu: więc na znalezienie przypadków trafu na wrzucenie iednego tylko Asa a nie więcey, trzeba nam od pierwszych czterech odciągnąc trzy pierwsze terminy, zostanie nam się termin $4 a b^{3}$ a zatem podobieństwo trafu $=\frac{4 a b^{3}}{(a+b)^{4}}$ $=\frac{500}{1296}=\frac{125}{324}$ co się zupełnie zgadza z Przykł: VII.

To ieszcze okazać można przez §. 11. wktórym wyłożyliśmy znaczenie każdego terminu funkcyi $(a+b)^{n}$, skąd wypada że termin $4 a b^{3}$ wyraża wrzucenie iednego tylko Asa, bo $a$ wyniesione w nim iest do pierwszy tylko potęgi. A zatem w ogólności mowiąć wszystkie podobne pytania, w którychbyśmy sobie założyli wrzucić liczbę tylko $l$ Asów a nie więcey, rozwiążą się przez ieden tylko termin w których się znayduie potęga $a b^{n-l}$; wynalezienie współczynnika tego terminu złożonego z Mnożników $n, \frac{n-1}{2}, \frac{n-2}{3}, \frac{n-3}{4}$ i t.d. zależy od potęgi $n$ : co nie zamyka żadney trudności.

[następna strona; brak numeracji]

\section{Przydatek do \$. 13}

$\underline{\text { Rachunek Losów }}$

Za pomocą sposobu w tym §. wyłożonego, możemy rozwiązać Pytania, iakieśmy mieli w Przykładach VIII. IX. i X.: i na dwoch graczów $A, B$ naznaczaiąc różną liczbę brakuiących punktów czyli grów do otrzymania zupełney wygrany, znaleśdź można Podobieństwo który z nich wprzód grę zakończy i wygra, a stąd wyciągnąc stósunek losów, sktórego ułożyć można Tablicę na różne przypadki. Nie będzie od rzeczy przyłączyć tu małą Tablicę przykładów: w których wystawiamy sobie że liczba brakuiących punktów każdemu Graczowi do 
zakończenia gry nie przewyższa 6 , i że obydwie strony z równą zręczNr 13(19) nością graią.

Punkta czyli gry Stósunek losów Punkta czyli gry Stósunek losów brakuiące do wygrany brakuiące do wygrany

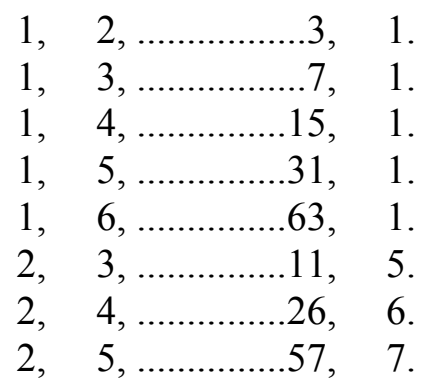

$2, \ldots .6$ 120. 8

.

$3, \ldots .4$

42. ....22

$3, \ldots .5$

$99, \ldots .29$

$3, \ldots .6$

$.219, \ldots . .37$

$4, \ldots 5$

$.163, \ldots . .93$

$4, \ldots .6$

$382, \ldots 130$

$5, \ldots .6$

$. .638, \ldots 386$

do wyrachowania tey Tablicy, dosyć iest położyć za $l$. p punkta brakuiące $\mathrm{w}$ kolumnie pierwszey, a ponieważ obydwie strony $\mathrm{z}$ równą zręcznością graią więc $\mathrm{w}$ tym założeniu $a=1, b=1$, wyniosłszy więc $a+b$ do potęgi $l+p-1$, wziąć należy liczbę $p$ terminów pierwszych i liczbę $l$ terminów ostatnich, w nich $a=b=1$, a stąd wypadaiące liczby dadzą stósunek losów odpowiadaiący założeniu. I tak w przykładzie 7 gdzie $A$ brakuie 2, a $B$ brakuie 4 grów do kończenia, tu $l=4, p=2$, $l+p-1=5, \quad(a+b)^{5}=a^{5}+5 a^{4} b+10 a^{3} b^{2}+10 a^{2} b^{3}+5 a b^{4}+b^{5} ;$ pierwsze dwa terminy kiedy $a=1, b=1$, wynoszą 6 ; a cztery ostatnie wynoszą 26 , skąd stósunek losów $=26$ : do 6 . tak iak w Tablicy. 


\section{rypatak do 913}

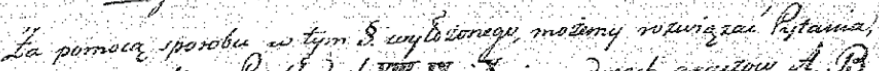

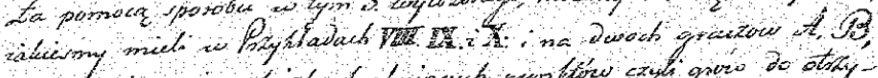

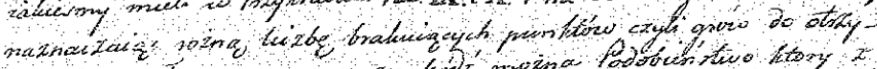

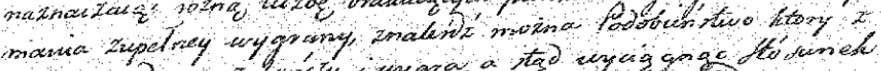

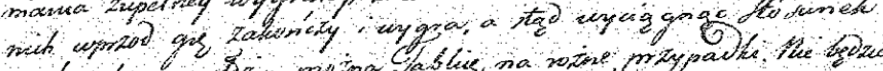

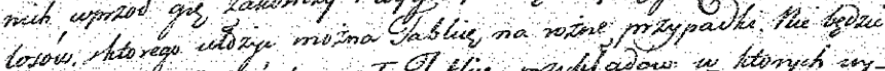

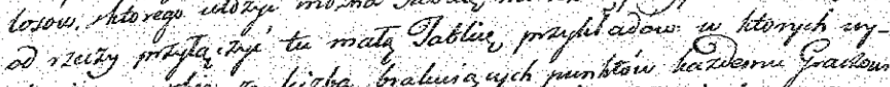

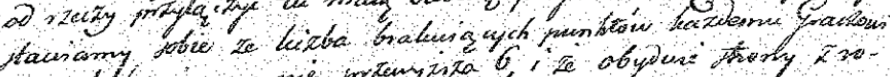

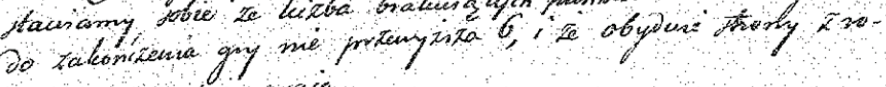
ang zoconusug graca

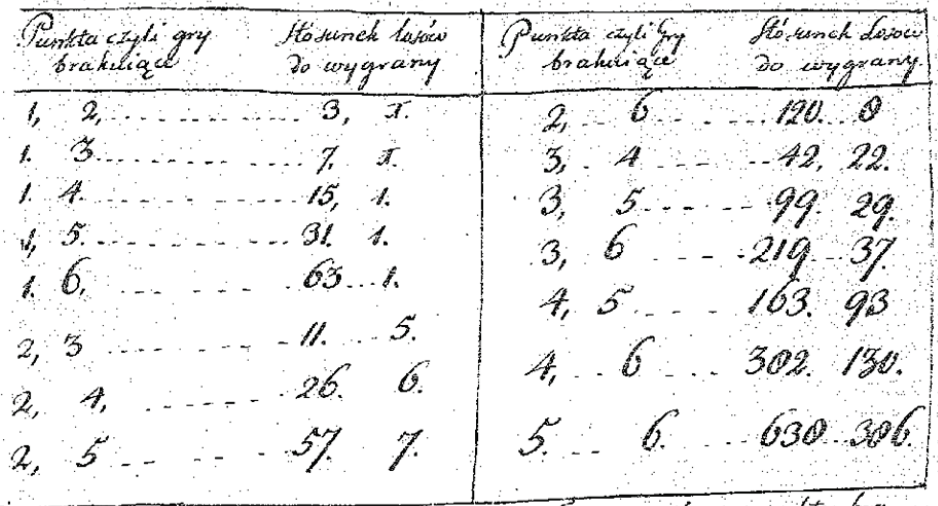

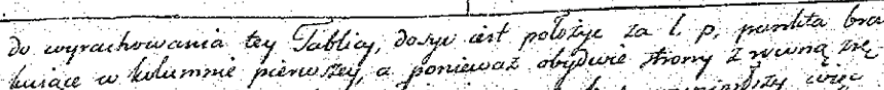

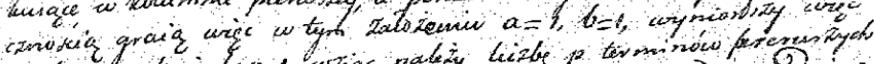

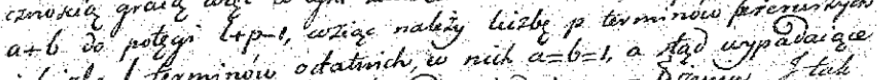

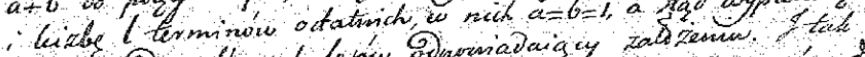

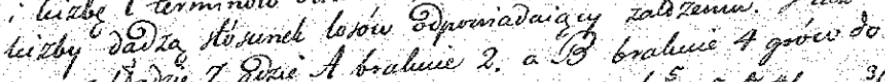

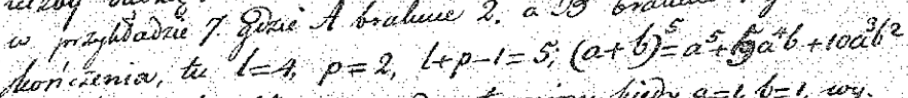
$+10 a^{2} b^{3}, a b^{4}+b^{5}$ percist owa terminy fiedy $a-b b=1$ woy.

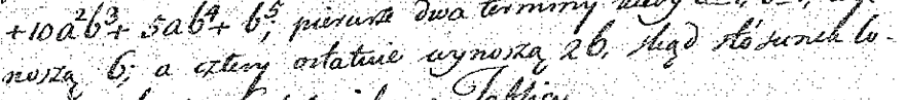

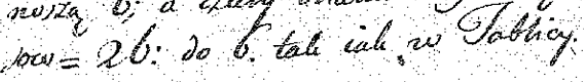

Rys. 2. Ostatnia strona rękopisu [4] Jana Śniadeckiego. 